\title{
KONSEP PENGEMBANGAN PENDEKATAN STRUKTUR DALAM PERJANJIAN PENETAPAN HARGA PADA PUTUSAN KPPU
}

\begin{abstract}
Azizah $^{1}$
Abstract

Structure Approach or Structure Analysis or Market Strength Analysis is a market structure approach or market strukture analysis which has strategic properties and strongly related to market behavior and market performance. Market Structure Analysis could being taken as an alternative analysis completion (The 4th KPPU Rule Year 2011), which could be used by KPPU to sentence the business actors whom trespass the Article 5 of 5th Law Year 1999 about Price Fixing Agreement. In ius constituendum, this analysis is argued to be the main alternative for KPPU, in order to minimize the rejection of KPPU decisions at State Court stage or at Supreme Court stage.
\end{abstract}

Keywords: structure approach, market strength analysis, alternative analysis completion, price fixing agreement

\begin{abstract}
Abstrak
Pendekatan struktur atau analisis struktur atau analisis kekuatan pasar merupakan suatu pendekatan struktur pasar atau analisis struktur pasar yang memiliki ciri-ciri strategis dan berkaitan erat dengan perilaku pasar dan kinerja pasar. Analisis struktur pasar dapat dijadikan alternatif analisis tambahan (Peraturan Komisi Pengawas Persaingan Usaha/KPPU, Nomor 4 Tahun 2011), yang dapat digunakan oleh Komisi untuk mengambil keputusan terhadap pelaku usaha yang melanggar ketentuan Pasal 5 undang-undang nomor 5 Tahun 1999 mengenai perjanjian penetapan harga. Dalam ius constituendum, hendaknya analisis ini dapat dijadikan alternatif utama bagi KPPU, sehingga akan meminimalisir putusan yang ditolak di tingkat Pengadilan negeri maupun mahkamah agung.
\end{abstract}

Kata kunci: pendekatan struktur, analisis kekuatan pasar, alternatif analysis tambahan, perjanjian penetapan harga

\section{Pendahuluan}

Eksistensi dan orientasi dari undang-undang Antimonopoli adalah untuk menciptakan persaingan usaha yang sehat dengan cara mencegah monopoli dan

1 Staf Pengajar Universitas PGRI Palembang dan FH Universitas Taman Siswa Palembang serta Mhs Program Doktor Ilmu Hukum Universitas Sriwijaya. Alamat kontak: azizah@ univpgri-palembang.ac.id. 
persaingan usaha yang tidak sehat, serta menciptakan ekonomi pasar yang efektif dan efisien untuk peningkatan kesejahteraan rakyat.

Persaingan usaha yang sehat merupakan salah satu kunci sukses bagi sistem ekonomi pasar yang wajar. Dalam implementasinya, hal tersebut diwujudkan dalam dua hal, yaitu, melalui penegakan hukum persaingan usaha dan melalui kebijakan persaingan yang kondusif terhadap perkembangan sektor ekonomi. $^{2}$

Untuk mencegah timbulnya persaingan usaha yang tidak sehat, maka Undang-Undang Nomor 5 Tahun 1999 mengatur secara jelas dan terstruktur tentang perjanjian yang dilarang, kegiatan yang dilarang dan posisi dominan. Sehubungan dengan 3 (tiga) hal tersebut, maka secara substansial berpotensi membuka peluang besar untuk terjadinya praktik monopoli dan persaingan usaha yang tidak sehat, apalagi sebagian besar transaksi bisnis memang berdasarkan perjanjian antara pelaku usaha.

Perjanjian penetapan harga diatur dalam Pasal 5 Undang-Undang Nomor 5 Tahun 1999. Pasal 5 memuat ketentuan bahwa:

\section{Pelaku usaha dilarang membuat perjanjian dengan pelaku usaha pesaingnya untuk menetapkan harga atas suatu barang dan atau jasa yang harus dibayar oleh konsumen atau pelanggan pada pasar bersangkutan yang sama.}

Berkaitan dengan penetapan harga tersebut, KPPU telah mengeluarkan Peraturan Nomor 4 Tahun 2011 tentang Pedoman Pasal 5 yang dimaksud. Dalam peraturan tersebut dijelaskan bahwa ada analisis pendekatan tambahan yang diperlukan oleh KPPU dalam memutus perkara. Analisis pendekatan yang dimaksud, berupa: analisis pendekatan rasionalitas penetapan harga, analisis pendekatan struktur pasar, analisis pendekatan data kinerja dan analisis pendekatan penggunaan fasilitas kolusi.

Selanjutnya dalam peraturan komisi yang dimaksud, juga dijelaskan bahwa dalam upaya pembuktian, maka tidak seluruh alat analisis pendekatan tambahan tersebut harus dipenuhi. Komisi dalam hal ini dapat memutuskan bahwa alat analisis pendekatan tertentu telah cukup digunakan untuk membuktikan pelanggaran Pasal 5 Undang-Undang Nomor 5 Tahun 1999.

Untuk menyatakan bahwa tindakan penetapan harga bersama di suatu pasar tersebut telah melanggar undang-undang nomor 5 Tahun 1999, maka yang dilihat bukan hanya penetapan harga bersama saja, kemungkinan akan terjadi bahwa penetapan harga bersama tersebut masih belum per-se (dengan sendirinya) melanggar. Pasal ini bersifat per-se yang tidak mengharuskan melihat implikasi atau adanya hambatan persaingan usaha. ${ }^{3}$ Akan tetapi juga

\footnotetext{
2 Hermansyah, "Pokok-Pokok Hukum Persaingan Usaha di Indonesia", (Jakarta: Kencana Prenada Media Group, 2009), hal. 15.

3 Mustafa Kamal Rokan, "Hukum Persaingan Usaha (Teori dan Praktiknya di Indonesia)", (Jakarta: PT. RajaGrafindo Persada, 2010), hal. 85.
} 
ditinjau efek negatifnya terhadap pasar, struktur pasar, cara melakukan penetapan harga bersama dan lain-lain yang relevan.

Untuk mengkaji keterkaitan antara pendekatan struktur dalam perjanjian penetapan harga dalam hubungannya dengan putusan KPPU, akan terurai berikut.

\section{Pembahasan.}

\section{Kajian tentang Perjanjian Penetapan Harga.}

Secara terminologi, monopoli ${ }^{4}$ adalah sisi lain dari theoritical coin dari kompetisi yang sempurna, sebagaimana yang dikemukakan oleh Ernest Gellhorn dan William E. Kovocic, yaitu:

In general terms, private monopolly is the other side of the critical coin of perpect competition. A seller with monopoly power restricts her output in order to raise her price and maximize her profits. Not only does this transfer wealth from consumers to producers, but it also reduces output and may relieve the producer of pressure to innovate or otherwise be efficient..$^{5}$

Yuichi Shionoya dalam bukunya Economy and Morality, menyatakan bahwa persaingan merupakan sebuah gambaran dari suatu permainan, seperti yang dikemukakannya bahwa:

Competition in markets is often compared to games to the rules of the game. Sosial acitivities can be conceived as games that competing participants play under certain rules. This ilustrates the use of a metaphor in economic discourse. Metaphors make problems intelligible by reference to simpler and more familier problem. ${ }^{6}$

Pasal 1313 Kitab Undang-Undang Hukum Perdata (KUH. Perdata), menyatakan bahwa: "Suatu perjanjian adalah suatu perbuatan hukum yang terjadi antara satu orang atau lebih mengikatkan dirinya terhadap

4 Boediono, "Ekonomi Mikro", (Yogyakarta: BPFE, 2010), hal. 125. Menurut Boediono, monopoli dapat diartikan sebagai suatu keadaan di mana di dalam pasar hanya ada satu penjual, sehingga tidak ada pihak lain yang menyainginya. Hal ini merupakan kasus monopoli murni atau pure monopol".

5 Ernest Gellhorn dan William E. Kovacic, "Antitrust Law and Economics in a Nutshell”, (USA: West Publishing Co., 1994), hal. 58.

${ }^{6}$ Yuichi Shionoya, "Economy and Morality: The Philosophy of The Welfare State", (Usa: Edward Elgar Publishing Inc., 2005), hal. 148. 
orang lain atau lebih". Subekti menyatakan bahwa: Perjanjian merupakan suatu peristiwa dimana seorang berjanji kepada seorang lain atau dimana dua orang itu saling berjanji untuk melaksanakan sesuatu hal. ${ }^{7}$ Sedangkan Wirjono Prodjodikoro menyatakan bahwa perjanjian merupakan suatu perhubungan hukum mengenai harta benda antara dua pihak, dalam mana suatu pihak berjanji atau dianggap berjanji untuk melakukan sesuatu hal atau untuk melakukan sesuatu hal, sedang pihak lain berhak menuntut pelaksanaan janji tersebut. ${ }^{8}$

Pasal 1 angka 7 Undang-Undang Nomor 5 Tahun 1999 merumuskan bahwa:

Perjanjian adalah suatu perbuatan satu atau lebih pelaku usaha untuk mengikatkan diri terhadap satu atau lebih pelaku usaha lain dengan nama apapun, baik tertulis maupun tidak tertulis.

Dengan demikian, perumusan perjanjian yang terdapat dalam undang-undang ini bersifat limitatif yang juga mencakup perjanjian tidak tertulis. Perjanjian yang dimaksud dapat berbentuk perjanjian penetapan harga.

Di dalam suatu perjanjian, terdapat unsur esensialia, naturalia dan aksidentalia. ${ }^{9}$ Unsur esensialia merupakan unsur yang harus ada di dalam perjanjian, sifat yang menentukan atau menyebabkan perjanjian itu tercipta (constructieve oordeel), seperti: sebab yang halal yang harus ada dalam perjanjian. Unsur naturalia merupakan unsur bawaan (natuur) dari perjanjian, sehingga secara diam-diam melekat pada perjanjian, seperti: menjamin bahwa tidak ada cacat dari benda yang dijual. Sedangkan unsur aksidentalia merupakan unsur yang melekat pada perjanjian yang secara tegas diperjanjikan oleh para pihak. ${ }^{10}$

Pasal 1320 KUH. Perdata, mengatur tentang syarat sahnya suatu perjanjian, yaitu:

1) Sepakat mereka yang mengikatkan dirinya;

2) Cakap untuk membuat suatu perjanjian;

3) Mengenai suatu hal tertentu;

4) Suatu sebab yang halal.

Sepakat dalam hal ini dimaksudkan bahwa kedua subjek yang mengadakan perjanjian itu harus bersepakat, setuju mengenai hal-hal

\footnotetext{
${ }^{7}$ Subekti, “Hukum Perjanjian”, (Jakarta: PT. Intermasa, 1987), hal. 1.

${ }^{8}$ Wirjono Prodjodikoro, “Asas-Asas Hukum Perjanjian”, (Bandung: Sumur Bandung, 1981), hal. 9.

${ }^{9}$ J. Satrio, "Hukum Perjanjian”, (Bandung: Citra Aditya Bakti, 1992), hal. 57.

${ }^{10}$ Mariam Darus Badrulzaman, 1994, “Aneka Hukum Bisnis”, (Bandung: Alumni, 1994), hal. 25.
} 
yang pokok dari perjanjian yang diadakan tersebut. Apa yang dikehendaki oleh satu pihak, juga dikehendaki oleh pihak yang lain. Mereka dalam hal ini menghendaki sesuatu yang sama secara timbal balik. $^{11}$

Orang yang membuat suatu perjanjian harus cakap menurut hukum. Pada asasnya, setiap orang yang telah dewasa dan sehat pikirannya, adalah cakap untuk bertindak, cakap melakukan tindakan hukum. Ketidakcakapan merupakan suatu perkecualian atas hal tersebut dan orang hanya tidak cakap, ketika undang-undang menyatakan demikian. ${ }^{12}$

Suatu perjanjian harus mengenai suatu hal yang tertentu, artinya apa yang diperjanjikan hak-hak dan kewajiban kedua belah pihak jika timbul suatu perselisihan. Sedangkan sebab atau causa yang halal dari suatu perjanjian adalah isi dari perjanjian itu sendiri, seperti: dalam perjanjian jual beli, maka isinya adalah pihak yang satu menghendaki sejumlah uang dan pihak lain berkewajiban membayarnya. ${ }^{13}$

Di dalam perjanjian, terdapat asas-asas fundamental berupa: asas konsensualisme, asas kekuatan mengikat perjanjian dan asas kebebasan berkontrak. Asas konsensualime menganggap bahwa perjanjian terbentuk karena adanya perjumpaan kehendak (consensus) dari para pihak. Perjanjian dalam hal ini dapat dibuat bebas, tidak terikat bentuk dan tercapai tidaknya secara formil, namun cukup melalui konsensus belaka. Asas kekuatan mengikat perjanjian menganggap bahwa para pihak harus memenuhi apa yang disepakati dalam perjanjian yang telah dibuat. Asas kebebasan berkontrak menganggap bahwa para pihak dapat membuat perjanjian dan setiap orang bebas mengikatkan diri dengan siapapun sesuai kehendak para pihak. Selain itu, para pihak bebas menentukan cakupan isi serta persyaratan dari suatu perjanjian, dengan ketentuan bahwa perjanjian tersebut tidak boleh bertentangan dengan peraturan perundang-undangan yang bersifat memaksa, ketertiban umum dan kesusilaan. $^{14}$

Sutan Remi Syahdeini sebagaimana dikutip Agus Yudha Hernoko, berpendapat bahwa asas kebebasan berkontrak menurut hukum perjanjian Indonesia, meliputi:

1) Kebebasan untuk membuat atau tidak membuat perjanjian;

2) Kebebasan untuk memilih pihak dengan siapa ia ingin membuat perjanjian;

\footnotetext{
${ }^{11}$ Subekti, Op. Cit., hal. 17.
}

${ }^{12}$ J. Satrio, O.p. Cit., hal. 277.

${ }^{13}$ Subekti, Op. Cit., hal. 19-20.

${ }^{14}$ Herlien Boediono, 2006, “Asas Keseimbangan bagi Hukum Perjanjian Indonesia: Hukum Perjanjian Berlandaskan Asas-Asas Wigati Indonesia”, (Bandung: Citra Aditya Bakti, 2006), hal. 94-96. 
3) Kebebasan untuk menentukan atau memilih kausa dari perjanjian yang akan dibuatnya;

4) Kebebasan untuk menentukan objek perjanjian;

5) Kebebasan untuk menentukan bentuk suatu perjanjian;

6) Kebebasan untuk menerima atau menyimpangi ketentuan undang-undang yang bersifat opsional. ${ }^{15}$

Asas kebebasan berkontrak tidak mempunyai arti yang tidak terbatas, akan tetapi terbatas oleh tanggung jawab para pihak, sehingga kebebasan berkontrak sebagai asas diberi sifat sebagai asas kebebasan berkontrak yang bertanggung jawab. Asas ini mendukung kedudukan yang seimbang antara para pihak, sehingga sebuah perjanjian akan bersifat stabil dan memberikan keuntungan bagi para pihak yang membuat perjanjian tersebut. $^{16}$ Keseimbangan dalam perjanjian yang dimaksud, juga termasuk dalam proses penentuan harga oleh para pihak.

Peranan harga berpengaruh terhadap keputusan produsen dalam menentukan tingkat output yang akan dihasilkan dan tingkat kombinasi penggunaan input untuk menghasilkan output. Proses penentuan harga yang dibuat oleh produsen dengan memperkirakan output dan input ini akan mengarah pada penetapan harga oleh pelaku usaha. ${ }^{17}$

Penetapan harga oleh produsen dalam hal ini dikecualikan terhadap cabang produksi yang penting dan/atau menguasai hajat hidup orang banyak. Mahkamah Konstitusi dalam putusan perkara nomor 002/PUU1/2003 tentang putusan pengujian Undang-Undang Migas Nomor 22 Tahun 2001, mencabut atau menyatakan bahwa Pasal 28 ayat (2) Undang-Undang Nomor 22 Tahun 2001, yang berbunyi "harga bahan bakar minyak dan harga gas bumi diserahkan pada mekanisme persaingan usaha yang sehat dan wajar", tidak mempunyai kekuatan hukum mengikat.

Mahkamah Konstitusi berpendapat bahwa untuk mencegah timbulnya praktik yang tidak sehat, maka seharusnya penetapan harga bahan bakar minyak dan gas bumi dalam negeri ditetapkan oleh pemerintah dengan memperhatikan kepentingan golongan masyarakat tertentu dan mempertimbangkan mekanisme persaingan usaha yang sehat dan wajar. Oleh karena itu, penetapan harga dalam penulisan ini dibatasi atau dikecualikan terhadap penetapan harga yang dimaksud dalam Undang-Undang Nomor 22 Tahun 2001 tersebut di atas, hal mana dikarenakan merujuk pada ketentuan Pasal 33 UUD 1945.

Dengan demikian, perjanjian dalam hal ini merupakan suatu perjanjian yang berbentuk tertulis dan tidak tertulis, yang memenuhi

\footnotetext{
15 Agus Yudha Hernoko, "Hukum Perjanjian: Asas Proporsionalitas dalam Kontrak Komersial”, (Jakarta: Kencana Prenada Media Group, 2011), hal. 110-111.

${ }^{16}$ Mariam Darus Badrulzaman, Op. Cit., hal. 45.

${ }^{17}$ Boediono, Op. Cit., hal. 169.
} 
unsur-unsur perjanjian, syarat sah perjanjian dan asas-asas hukum perjanjian khususnya asas keseimbangan yang berkaitan dengan penetapan harga yang dibuat oleh para pelaku usaha.

Mengikatnya suatu perjanjian penetapan harga, terkait dengan asas yang melekat di dalamnya yang bersandar pada faktor idiil dan riil. Faktor idiil yang dimaksud, dilandaskan pada Pancasila dan faktor riil muncul dari hukum positif dan praktik hukum di Indonesia. Asas yang melekat tersebut dinamakan asas keseimbangan. ${ }^{18}$

Terdapat hubungan antara analisis pendekatan struktur dalam perjanjian penetapan harga terhadap keseimbangan. Pelaku usaha yang melakukan perjanjian penetapan harga akan mengabaikan keseimbangan kepentingan pelaku usaha lainnya serta masyarakat selaku konsumen. Analisis struktur merupakan suatu pendekatan dimana agar suatu tindakan dari pelaku pasar dapat dikatakan melanggar hukum anti monopoli, maka disamping dianalisis terhadap tindakan yang dilakukan tersebut, juga dilihat pada kekuatan pasar atau struktur pasar. ${ }^{19}$

Terdapat contoh perkara perjanjian penetapan harga. Misalnya: Putusan perkara nomor 08/KPP-1/2005; Putusan Pengadilan Negeri Jakarta Selatan nomor 01/KPPU2006/PN. Jak-Sel; Putusan Mahkamah Agung Nomor 03 K/KPPU/2006 tentang Penyediaan Jasa Survei Gula Impor, bahwa PT. Surveyor Indonesia (Persero) dan PT Superintending Company of Indonesia (Persero) telah bersepakat atau mengikatkan diri dalam suatu Memorandum of Understanding membentuk KSO untuk pelaksanaan verifikasi atau penelusuran teknis impor gula. Sedangkan putusan perkara nomor 11/KPPU-1/2005; Putusan Pengadilan Negeri Surabaya nomor 24/Pdt.G/2006/PN-SBY; Putusan Mahkamah Agung nomor $05 \mathrm{~K} / \mathrm{KPPU} 2007$ tentang dugaan adanya perjanjian dan pelanggaran terhadap Pasal 5 Undang-undang Nomor 5 Tahun 1999 yang dilakukan oleh Konsorsium dalam bentuk mewajibkan pasar untuk menjual Semen Gresik.

\section{Kajian tentang Pendekatan Struktur.}

Pendekatan struktur atau analisis struktur atau analisis kekuatan pasar merupakan suatu pendekatan struktur pasar yang memiliki ciri-ciri strategis dan berkaitan erat dengan perilaku pasar dan kinerja pasar, yang memiliki unsur-unsur sebagai berikut:

1) Pemusatan penjual dan pemusatan pembeli yang diukur melalui jumlah penjual dan pembeli;

2) Persyaratan masuk pasar;

\footnotetext{
${ }^{18}$ Herlien Budiono, Op. Cit., hal. 13-14.
}

19 Munir Fuady, "Hukum Anti Monopoli, Menyongsong Era Persaingan Sehat", (Bandung: Citra Aditya Bakti, 2003), hal. 48. 
3) Sifat produk yang ditawarkan apakah homogen ataukah ada pembedaan produk;

4) Tingkat dimana perusahaan memproduksi dan menjual sendiri secara langsung atau menciptakan sendiri saluran distribusi untuk produk-produknya;

5) Tingkat dimana perusahaan beroperasi dalam sejumlah pasar atau hanya dalam satu pasar. ${ }^{20}$

Kinerja pasar menggambarkan efisiensi dari suatu pasar dalam menggunakan sumberdaya yang langka untuk memenuhi permintaan konsumen terhadap barang dan jasa. Efisiensi yang dimaksud adalah seberapa baik suatu pasar dapat memberikan kontribusi pada optimalisasi kesejahteraan ekonomi. Elemen kinerja pasar dapat mencakup: pertama, efisiensi produksi yang mencerminkan kemampuan perusahaan untuk menghasilkan produk yang bermutu dengan harga yang bersaing. Kedua, efisiensi alokasi, yaitu tingkat dimana harga pasar yang dibebankan pada para pembeli, selaras dengan biaya pemasaran termasuk pengembalian suatu laba normal pada produk. Ketiga, kemajuan teknologi yang menyangkut kemampuan para pelaku pasar/pemasok untuk selalu memperkenalkan teknik distribusi dan produksi baru yang hemat biaya dan memperkenalkan produk-produk unggul. Keempat, kinerja produk yang menyangkut kehandalan, kualitas dan keanekaragaman produk yang ditawarkan oleh para pelaku pasar/pemasok. ${ }^{21}$

Secara teoretis, perilaku pasar direfleksikan berdasarkan elemenelemen berupa: pertama, tujuan perusahaan seperti perolehan laba, target pertumbuhan aktiva dan penjualan. Kedua, metode persaingan yang digunakan untuk mencapai tujuan tersebut, khususnya mengenai kebijakan tentang tingkat output dan harga serta pembedaan produk. Ketiga, perilaku antar peusahaan mengenai tingkat dimana perusahaan berada dalam satu pasar yang bersaing atau tingkat dimana perusahaan tersebut mencari titik temu dari perilaku penetapan harga mereka. ${ }^{22}$ Dengan demikian, perilaku pasar berkaitan dengan pelaku pasar yang berinteraksi dalam pasar.

Istilah struktur pasar (market structure) mengacu pada semua aspek yang dapat mempengaruhi perilaku dan kinerja perusahaan di suatu pasar (misalnya: jumlah perusahaan di pasar atau jenis produk yang dijual) Sedangkan pasar dapat didefinisikan sebagai suatu daerah tempat pembeli dan penjual dapat merundingkan pertukaran komoditas tertentu. $^{23}$

${ }^{20}$ Johnny Ibrahim, "Pendekatan Ekonomi terhadap Hukum: Teori dan Implikasi Penerapannya di Indonesia”, (Malang: Bayumedia Publishing, tanpa tahun), hal. 146.

${ }^{21}$ Ibid., hal. 146-147.

${ }^{22}$ Ibid., hal. 142-144. 
Menurut ketentuan Pasal 1 angka 9 Undang-Undang Nomor 5 Tahun 1999, pasar dapat diartikan sebagai lembaga ekonomi di mana para pembeli dn penjual baik secara langsung maupun tidak langsung dapat melakukan transaksi perdagangan barang dan atau jasa.

Para ahli ekonomi mendefinisikan struktur pasar sebagai karakteristik yang mempengaruhi perilaku dan kinerja perusahaan yang menjual di pasar tersebut. Karakteristik-karakteristik ini menentukan antara lain hubungan antara kurva permintaan pasar untuk produk industri dan kurva perimintaan yang dihadapi masing-masing perusahaan dalam industri tersebut. ${ }^{24}$

Menurut Pasal 1 angka 11 Undang-Undang Nomor 5 Tahun 1999, struktur pasar dapat diartikan sebagai:

Keadaan pasar yang memberikan petunjuk tentang aspekaspek yang memiliki pengaruh penting terhadap perilaku pelaku usaha dan kinerja pasar, antara lain jumlah penjual dan pembeli, hambatan masuk dan keluar pasar, keragaman produk, sistem distribusi dan penguasaan pangsa pasar.

Pengertian lain tentang struktur pasar yaitu cara suatu pasar diorganisasikan. Berdasarkan ciri-ciri jenis barang dan jasa yang dihasilkan, banyaknya perusahaan dalam kegiatan untuk menghasilkan barang tersebut, ada tidaknya rintangan serta mudah atau tidaknya perusahaan baru masuk dan menjalankan kegiatan untuk memproduksi barang tersebut. ${ }^{25}$

Dari pengertian struktur pasar yang tertera dalam Pasal 1 angka 11 Undang-Undang Nomor 5 Tahun 1999 tersebut, maka unsur-unsur pengertian struktur pasar terdiri dari:

1) Keadaan pasar;

2) Adanya petunjuk;

3) Memiliki pengaruh terhadap perilaku pelaku usaha dan kinerja pasar.

Peraturan KPPU nomor 4 Tahun 2011 tentang Pedoman Pasal 5 (Penetapan Harga) Undang-Undang Nomor 5 Tahun 1999 tentang Larangan Praktek Monopoli dan Persaingan Usaha tidak Sehat mengatur tentang analisis struktur pasar yang dapat digunakan sebagai salah satu analisis tambahan yang dapat dijadikan bukti tidak langsung, yang dalam hal ini untuk membedakan parallel business conduct dengan illegal agreement.

${ }^{23}$ Richard G. Lipsey; Paul N.Courant; Douglas D. Purvis; Peter O. Steiner (Alih bahasa oleh Agus Maulana dan Lyndon Saputra), "Pengantar Mikro Ekonomi", (Jakarta: Binarupa Aksara, 1997), hal. 3-4.

${ }^{24}$ Ibid.

${ }^{25}$ Johnny Ibrahim, Op. Cit., hal. 141. 
Di dalam pedoman Pasal 5 yang dimaksud, diuraikan bahwa untuk membuktikan telah terjadinya pelanggaran terhadap ketentuan Pasal 5 Undang-Undang Nomor 5 Tahun 1999, diperlukan adanya perjanjian di antara pelaku usaha independen yang sedang bersaing dalam menetapkan harga atas barang dan atau jasa. Perilaku penetapan harga para pelaku usaha di pasar tersebut dilakukan secara bersama-sama. Tindakan perusahaan yang bersifat independen dari perilaku perusahaan lain, bukanlah merupakan pelanggaran terhadap hukum persaingan.

Selanjutnya di dalam pedoman Pasal 5 tersbut, juga diuraikan bahwa bentuk perjanjian tertulis tidak menjadi keharusan dalam membuktikan adanya suatu perjanjian perilaku penetapan harga sebagaimana yang diatur dalam Pasal 1 angka 7 Undang-Undang nomor 5 Tahun 1999, yaitu: "Perjanjian adalah suatu perbuatan satu atau lebih pelaku usaha untuk mengikatkan diri terhadap satu atau lebih pelaku usaha lain dengan nama apapun, baik tertulis maupun tidak tertulis".

Sisi lain yang diperlukan di sini adalah bukti bahwa penetapan harga dilakukan bersama-sama berdasarkan kesepakatan dari pelaku usaha. Bukti yang diperlukan tersebut dapat berupa bukti langsung dan bukti tidak langsung, yang terurai berikut:

\section{Bukti Langsung}

Bukti langsung merupakan bukti yang dapat diamati dan menunjukkan adanya suatu perjanjian penetapan harga atas barang dan atau jasa oleh pelaku usaha yang bersaing. Di dalam bukti langsung tesebut, terdapat kesepakatan dan substansi dari kesepakatan yang dimaksud. Bukti langsung dapat berupa faximile, rekaman percakapan telepon, surat elektronik, komunikasi video dan bukti nyata lainnya.

\section{Bukti tidak Langsung.}

Bukti tidak langsung adalah suatu bentuk bukti yang tidak secara langsung menyatakan adanya kesepakatan penetapan harga. Bukti tidak langsung dapat digunakan sebagai pembuktian terhadap terjadinya suatu keadaan/kondisi yang dapat dijadikan dugaan atau pemberlakuan suatu perjanjian tidak tertulis. Bukti tidak langsung dapat berupa: bukti komunikasi (namun tidak secara langsung menyatakan kesepakatan) dan bukti ekonomi. Tujuan dari pembuktian bukti tidak langsung ini dengan menggunakan bukti ekonomi, adalah upaya untuk mengesampingkan kemungkinan terjadinya perilaku penetapan harga yang bersifat independen. Suatu bentuk bukti tidak langsung yang sesuai dan konsisten dengan kondisi persaingan dan kolusi, sekaligus belum dapat dijadikan bukti bahwa telah terjadi pelanggaran atas Pasal 5 Undang-Undang Nomor 5 Tahun 1999. 


\section{Konsep Pengembangan Pendekatan Struktur dalam Putusan KPPU sebagai Cita Hukum.}

Cita hukum bangsa yang berisikan gagasan dan pandangan dijadikan sebagai dasar pijakan dalam pembuatan konsep hukum. Gagasan dan proses penyusunan norma yang dilandasi pada cita hukum yang terarah, umumnya tercermin di dalam penormaan baik sebagai norma dasar, maupun sebagai alat yang berkaitan dengan perkembangan masyarakat, berdasarkan pada perencanaan sebagaimana yang diharapkan.

Konsep hukum sebagai alat atau sarana, secara tidak langsung menghantarkan pada pembahasan mengenai hukum sebagai konsep yang modern. Karakter hukum (undang-undang) yang diciptakan tidak jarng hanya sebagai alat untuk memaksakan sesuatu perbuatan atau peristiwa menjadi perbuatan hukum atau peristiwa hukum. ${ }^{26}$

Istilah "cita" secara harfiah mengandung pengertian sebagai rasa, perasaan hati atau cita-cita, kehendak yang dipikirkan terus menerus atau ide/gagasan. Cita hukum nasional dapat diartikan sebagai cita-cita dan apa yang kita pikirkan bersama mengenai hukum nasional dan apa serta bagaimana bentuk/perwujudan hukum nasional di masa datang.

Cita hukum nasional merupakan satu hal yang ingin dicapai dalam pengertian penerapan perwujudan dan pelaksanaan nilai-nilai tertentu di dalam tata kehidupan bernegara dan bermasyarakat di Indonesia, yang ber-asaskan Pancasila dan berdasarkan UUD 1945. Khusus dalam bidang kehidupan dan kegiatan ekonomi pada umumnya, dalam rangka menyongsong masyarakat global cita hukum nasional, maka sangat membutuhkan kajian dan pengembangan yang lebih bersungguh agar mampu ikut serta dalam tata kehidupan ekonomi global dengan aman dan pengertian tidak merugikan/dirugikan oleh pihak-pihak lain. ${ }^{27}$

Globalisasi $^{28}$ merupakan kata yang mengerikan dengan makna yang kabur, istilah ini dipakai pada tahun 1960-an, dan menjadi mode yang

\footnotetext{
${ }^{26}$ Romli Atmasasmita, 2012, Teori Hukum Integratif, Rekonstruksi Terhadap Teori Hukum Pembanguan dan Teori Hukum Progresif, Cetakan Pertama, Genta Publishing, Yogyakarta, hlm. xii.

27 Sri Redjeki Hartono, "Hukum Ekonomi Indonesia", (Malang: Bayumedia Publishing, 2007), hal. 3.

${ }^{28}$ Menurut Giddens seperti yang dikutip oleh Martin Wolf, "Globalisasi Jalan Menuju Kesejahteraan”,(Jakarta: Yayasan Obor Indonesia, 2007), globalisasi adalah kekuatan yang tak terbendung, mengubah segala aspek kontemporer dari masyarakat, politik, dan ekonomi. Sedangkan menurut Anne Krueger, globalisasi sebagai suatu fenomena dimana agen-agen ekonomi dibagian manapun didunia jauh lebih terkena dampak peristiwa yang terjadi ditempat lain didunia daripada sebelumnya. David Henderson mendefinisikan globalisasi sebagai pergerakan bebas barang, jasa, buruh dan modal, sehingga menciptakan satu pasar tunggal dalam hal masukan dan keluaran dan perlakuan bersifat nasional terhadap investor asing (serta warga nasional yang bekerja di luar negeri). Sehingga, dari segi ekonomi, tidak ada orang asing. Definisi lainnya diberikan oleh Brink Lindsey, yang menyatakan ada tiga makna
} 
makin populer pada tahun 1990-an. Bagi banyak pendukung globalisasi, hal itu merupakan kekuatan yang tak tertahankan yang diinginkan yang menyapu batas-batas, menjungkalkan pemerintah, memperlemah pemajakan, membebaskan individu dan memperkaya apa yang disentuhnya. Sedangkan bagi para penentangnya, hal tersebut juga merupakan kekuatan yang tak tertahankan dan sesuatu hal yang tak diinginkan. Dengan embel-embel neoliberal atau korporasi, globalisasi merupakan hal yang memiliki kekuatan jahat yang memiskinkan massa, menghancurkan budaya, memperlemah demokrasi, memaksakan Amerikanisasi, membasmi negara kesejahteraan, menghancurkan lingkungan hidup dan memuja keserakahan. Dilain pihak, globalisasi merupakan sesuatu hal yang sangat memuaskan dilihat dari pertimbangan segala aspek. ${ }^{29}$ Dilain pihak, David Ricardo ber-argumen bahwa globalisasi membawa keuntungan komparatif bagi negara yang terlibat didalamnya. $^{30}$

Memaknai globalisasi sendiri sesungguhnya bukan perkara yang mudah, karena banyaknya dimensi yang harus ditelisik. Setidaknya terdapat lima karakter penting dari globalisasi, yakni: 1) pertumbuhan transaksi keuangan internasional yang cepat; 2) pertumbuhan perdagangan yang cepat, terutama diantara perusahaan-perusahaan transnasional; 3) gelombang investasi asing langsung (foreign direct investment), yang mendapat dukungan luas dari kalangan perusahaan transnasional; 4) timbulnya pasar global; 5) penyebaran teknologi dan berbagai pemikiran sebagai akibat dari ekspansi sitem transportasi dan komunikasi yang cepat dan meliputi seluruh dunia. Dengan ciri tersebut, globalisiasi dengan sendirinya merupakan proses pemadatan (ekonomi) dunia. $^{31}$

Era Globalisasi Ekonomi telah dimulai, ${ }^{32}$ berbagai perjanjian multilateral disepakati serta pembentukan berbagai lembaga internasional

yang berbeda tapi saling berhubungan; pertama, untuk menggambarkan fenomena ekonomi dari peningkatan integrasi pasar lintas perbatasan politik; kedua, untuk menggambarkan fenomena politik yang terbatas mengenai runtuhnya rintangan-rintangan yang dipasang oleh pemerintah atas arus internasional barang, jasa dan modal; ketiga, untuk menggambarkan fenomena politik yang jauh lebih luas mengenai persebaran global kebijakan-kebijakan yang berorientasi pasar di lingkungan domestik dan internasional.

${ }^{29}$ Martin Wolf, Ibid., hal. 15.

30 Mikhael Dua, "Filsafat Ekonom: Upaya Mencari Kesejahteraan Bersama", (Yogyakarta: Kanisius, 2008), hal. 127

${ }^{31}$ Ahmad Erani Yustika, 2010, "Ekonomi Kelembagaan, Definisi, Teori dan Strategi”, (Malang: Bayumedia Publishing, 2010), hal. 11.

32 Jika kita perhatikan proses memasuki globalisasi di Indonesia lebih banyak didorong oleh pemerintah bukan sektor bisnis swasta, pelaku bisnis swasta di negeri justru cenderung merasa tidak siap untuk memasuki era globalisasi. Ketidaksiapan para pelaku ekonomi Indonesia dalam memasuki pasar bebas, membuat posisi Indonesia menjadi ragu 
dalam kerangka kerjasama ekonomi di berbagai wilayah, seperti NAFTA, APEC, AFTA, Uni Eropa, dan WTO. Terbentuknya tatanan ekonomi global merupakan kenyataan yang harus dihadapi oleh negaranegara berkembang di dunia, termasuk Indonesia ${ }^{33}$.Selain itu sejak awal 2010 telah diberlakukan ASEAN-China Free Trade Area (ACFTA) bagi Indonesia, ${ }^{34}$ hal mana juga mempengaruhi berbagai kondisi perekonomian Indonesia dalam era persaingan bebas.

Penjelasan alinea ke-2 undang-undang nomor 5 Tahun 1999 menyatakan bahwa, "Indonesia masih dihadapkan tantangan atau persoalan ekonomi khususnya dalam pembangunan ekonomi yang belum terpecahkan, hal mana diiringi dengan adanya globalisasi perekonomian serta dinamika perkembangan usaha swasta sejak awal tahun 1990-an”.

Bagi negara Indonesia di era globalisasi ekonomi, pembangunan hukum ekonomi nasional, hingga saat ini dianggap belum dapat mengakomodir semua perkembangan aktivitas bisnis nasional maupun internasional. Oleh karena itu, peran negara sebagai pembentuk peraturan khususnya peraturan di bidang persaingan usaha sangat menentukan dalam mencapai kondisi pembangunan perekonomian.

Berangkat dari uraian tentang analisis struktur pasar yang dapat dijadikan salah satu analisis tambahan berupa bukti tidak langsung bahwa di dalam pasar telah terjadi perjanjian penetapan harga, maka seyogyanya analisis struktur pasar harus benar-benar diterapkan dalam hal memperkuat pertimbangan komisi KPPU dalam konsep cita hukum di masa akan datang. Di lain sisi, jika dihubungkan dengan syarat sah perjanjian dalam ketentuan Pasal 1320 Kitab Undang-Undang Hukum Perdata, maka perjanjian penetapan harga telah memenuhi syarat objektif yaitu "causa tidak halal", sehingga perjanjian tersebut batal demi hukum.

\section{Penutup}

Pemaknaan dan berfungsinya asas keseimbangan dalam menjelaskan tujuan hukum persaingan usaha berdasarkan pancasila dan asas-asas hukum ekonomi dalam UUD 1945 (asas keadilan sosial, asas keman- faatan, asas

apakah kita siap memasuki AFTA apalagi APEC yang penuh tantangan dan persaingan itu. Suhanadji-Waspodo TS, "Modernisasi dan Globalisasi studi Pembangunan dalam Perspektif Global”, (Malang: Insan Cendekia, 2004), hal.141-142 dalam Joni Emirzon, Penerapan Otonomi Keilmuan Dalam Pembanguan Hukum Ekonomi di Era Globalisasi, Makalah Kualifikasi, Universitas Diponegoro, Semarang, 2005, hal.2.

${ }^{33}$ Dalam kenyataannya Negara Indonesia belum siap dihampir semua aspek untuk menghadapi era globalisasi ekonomi, hal ini terbukti pada saat krisis ekonomi melanda Negara Indonesia pada pertengahan tahun 1997 hingga saat ini masih bergelut menghadapi krisis ekonomi, bila dibandingkan dengan Negara-negara lain seperti Malaysia, Thailand, Korea Selatan.

34 Jonker Sihombing, "Peran dan Aspek Hukum Dalam Pembangunan Ekonomi", (Bandung: PT. Alumni, 2010), hal. 152. 
demokrasi ekonomi, asas kepastian hukum), yaitu meningkatkan kesejahteraan rakyat, menjamin kepastian kesempatan berusaha yang sama antara pelaku usaha, mencegah praktik monopoli dan persaingan usaha tidak sehat, serta efektifitas dan efisiensi dalam kegiatan usaha. Dalam pencapaian pemaknaan tersebut, maka konsep pengembangan pendekatan struktur dapat lebih diterapkan dan dikembangkan dalam putusan KPPU.

Di sisi lain, penggunaan analisis pendekatan struktur dalam pertimbangan hukum putusan KPPU, lebih dapat mencerminkan dan menambah nilai keadilan bagi para pihak (pelaku usaha sebagai terlapor, pelaku usaha pesaing serta konsumen). 


\section{Daftar Pustaka}

Atmasasmita, Romli. Teori Hukum Integratif, Rekonstruksi Terhadap Teori Hukum Pembangunan dan Teori Hukum Progresif, Cetakan Pertama, Yogyakarta: Genta Publishing, 2012.

Badrulzaman, Mariam Darus. Aneka HukumBisnis, Bandung: Alumni, 1994.

Boediono. Ekonomi Mikro, Yogyakarta: BPFE, 2010.

Budiono, Herlien. Asas Keseimbangan bagi Hukum Perjanjian Indonesia: Hukum Perjanjian Berlandaskan Asas-Asas Wigati Indonesia, Bandung: Citra Aditya Bakti, 2006.

Dua, Mikhael. Filsafat Ekonomi: Upaya Mencari Kesejahteraan Bersama, Yogyakarta: Kanisius, 2008.

Fuady, Munir Hukum Anti Monopoli, Menyongsong Era Persaingan Sehat, Bandung: PT. Citra Aditya Bakti, 2003.

Gelhorn, Ernest. Larangan Praktek Trust Law and Economic -in anut Shell, USA: West Publishing Co., 1986.

Hartono, Sri Redjeki. Hukum Ekonomi Indonesia, Malang: Bayumedia Publishing, 2007.

Hermansyah. Pokok-Pokok Hukum Persaingan Usaha di Indonesia, Jakarta: Kencana Prenada Media Group, 2009.

Hernoko, Agus Yudha. HukumPerjanjian: Asas Proporsionalitas dalam Kontrak Komersial, Jakarta: Kencana Prenada Media Group, 2011.

Ibrahim, Johnny. Pendekatan Ekonomi Terhadap Hukum:Teori dan Implikasi Penerapannya dalam Penegakan Hukum, Surabaya: CV. Putra Media Nusantara dan ITS Press, 2009.

Lipsey; Richard G., Paul N. Courant, Douglas D. Purvis, and Peter O. Steiner (alih bahasa oleh Agus Maulana dan Lyndon Saputra ), , Pengantar Mikro Ekonomi, Jakarta: Binarupa Aksara, 1997

Mustika, Ahmad Erani. Ekonomi Kelembagaan, Definisi, Teori dan Strategi, Malang: Bayumedia Publishing, 2011.

Prodjodikoro,Wirjono. Asas-Asas Hukum Perjanjian, Bandung: Sumur Bandung, 1981.

Rokan, Mustafa Kamal. HukumPersaingan Usaha (Teori dan Praktiknya di Indonesia, Jakarta: PT. Raja Grafindo Persada, 2010.

Wolf, Martin. Globalisasi Jalan Menuju Kesejahteraan, Jakarta: Yayasan Obor Indonesia, 2007.

Satrio, J. HukumPerjanjian, Bandung: Citra Aditya Bakti, 1992.

Subekti, Hukum Perjanjian, Jakarta: PT. Intermasa, 1987. 